\title{
Diagnostic Accuracy of Ultrasonography and Magnetic Resonance Imaging for Detection of Fetal Anomalies
}

\author{
ATINAS A.M.A. KANDIL, M.Sc.; MAHMOUD A. DAWOOD, M.D.; HAYTHAM H. ELSAEED, M.D. and \\ NOHA M.A. IBRAHIM, M.D.
}

The Department of Radiology, Faculty of Medicine, Tanta University

\begin{abstract}
Background: Three dimensional ultrasound is the standard modality used for the imaging of the fetus. It is widely available, easy to apply, cost-effective, safe for the fetus and allows real-time imaging. MR imaging is an alternative modality that uses no ionizing radiation, has excellent tissue contrast and a large field of view, is not limited by obesity or overlying bone, and can image the fetus in multiple planes, no matter the fetal lie. This study was carried out on 40 patients which have been suspected by $2 \mathrm{D}$ ultrasound as having fetal malformations. Post-natal evaluation was done by both imaging ( $2 \mathrm{D}$ ultrasound and $\mathrm{X}$-ray) and clinical examination, it was a criterion for our study to compare the accuracy of 3D ultrasonography and MR imaging in diagnosis of fetal malformations.
\end{abstract}

Aim of Study: To compare the precision and accuracy of 3D ultrasonography and MR imaging in diagnosis of fetal malformations and correlate their results with the postnatal findings.

Patients and Methods: This prospective study included fourty (40) pregnant female patients which have been suspected by $2 \mathrm{D}$ ultrasound as having fetal malformations.

Results: We have found that 7 cases of all patients were diagnosed as normal with no any congenital anomalies which represented $18 \%$ of all cases and 33 of those cases were diagnosed as abnormal cases who were clearly demonstrated congenital anomalies which represented $82 \%$ of all cases as suggested by MRI findings, however the results we have by 3D US were 6 cases who were diagnosed as normal which represented about $15 \%$ and 34 cases were diagnosed as abnormal cases which represented about $85 \%$ of all cases.

According to the postnatal final diagnosis which diagnosed by imaging or clinical examination, we have found that 8 cases from 40 cases were diagnosed as normal and 32 cases from 40 cases were diagnosed as abnormal.

Conclusion: MR imaging as an adjunct to prenatal 3D US may provide valuable information that could add to the prenatal evaluation and treatment of some fetal anomalies, particularly those involving the central nervous system.

Correspondence to: Dr. Atinas A.M.A. Kandil, The Department of Radiology, Faculty of Medicine, Tanta University
Key Words: 3D Ultrasound - MRI - Fetus; Malformations Congenital-Anomalies.

\section{Introduction}

SCREENING for fetal malformations has become the most important profile health care issues of modern obstetrics. US is the chief method for detecting congenital malformations [1]. Owing to the recent advances of 3D/4D US, they have assessed not only structural but also functional early developmental anomalies [2]. The introduction of 3D/4D US using high frequency transvaginal transducer produced remarkable progress on early fetal development both structural and functional [3] While is still the most commonly used modality in fetal imaging, MRI is increasingly used as an investigation during fetal life for assessment of congenital malformation [4] . Fetal MRI is increasingly used in clinical practice. It is a powerful modality to evaluate the fetal brain, fetal spine, and fetal body, and is a valuable complement to prenatal ultrasound [5]. Fetal MRI allows direct visualization of certain structures, such as the developing brain parenchyma and it isn't susceptible to the same limitations as ultrasound, and has higher contrast resolution than prenatal ultrasound [6]. Structural brain abnormalities, such as developmental malformations and destructive lesions, can be sonographically occult on prenatal ultrasound, yet detectable by fetal MRI [7]. The potential application of MRI as an alternative to US has its advantage and limitations, for example fetal motion was an important limitation in early studies, however the fast MRI sequence has overcome this problem, and also real time MRI allows most continuous imaging of the moving fetus [8]

\section{Patients and Methods}

This prospective study was carried out on 40 female pregnant patients attending Radiology and 
Medical imaging department of Tanta University Hospital in a duration from Septemper 2015 to May 2018.

Ultrasonographic evaluation was done on 16 patients using Toshiba Aplio 500 with multifrequency (3.5 to 5) transabdominal and (5 to $7 \mathrm{MHz}$ ) transvaginal volumetric probes and the remaining patients were examined using Samsung UGEO H60 machine (Samsung, Korea) with multifrequency (3.5 to 5) transabdominal and (5 to $7 \mathrm{MHz}$ ) transvaginal volumetric probes.

Fetal MRI routinely performed on GE SIGNA Explorer 1.5 Tesla scanners. An 8-channel torso phased array coil is used to allow increased coverage and increased signal -to-noise ratio over more standard pelvic phased array coils. The mother lies supine during the course of the examination, which typically lasts 45 minutes.

Written consent was obtained from the patients participating in this study after full explanation of the benefits of the procedure. Patients have been suspected as having fetal malformations by $2 \mathrm{D}$ ultrasound was included in this study. It is preferable to wait until at least 20 to 22 weeks' gestation to minimize the difficulties created by the small size of the fetus and the excessive motion of younger fetuses. Claustrophobic patients and cardiovascular anomalies was excluded.

\section{D Ultrasound MSV (multislice view) technique:}

Diagnostic work-up included an initial 2D ultrasound screening. Fetal viability will be examined, Biparietal diameter (BPD), and femur length (FL) and abdominal circumference (AC) was measured. Evaluation of fetal anatomy followed by obtaining the 3D ultrasound volume datasets of the fetal head, trunk and limbs will be obtained on the target organ with pathology. The acquired volumetric data were stored to enable full evaluation without loss of information at any time.

\section{MRI sequences:}

Coronal $\mathrm{T} 2$ weighted image with $\mathrm{TR}=3420$ and $\mathrm{TE}=106$, Coronal T1 weighted image with $\mathrm{TE}=680$ and $\mathrm{TE}=12.0$, Sagittal T2 with $\mathrm{TR}=1400$ and $\mathrm{TE}=97.4$, Axial T2 weighted image with $\mathrm{TR}=1400$ and $\mathrm{TE}=102$. Typically, an initial localizer is obtained in three orthogonal planes with respect to the mother, using 6 to $8 \mathrm{~mm}$ thick slices with 1 to $2 \mathrm{~mm}$ gap and a large field of view. The localizer is useful for visualizing the position of the fetus and determining fetal sidedness. We also use this localizer to ensure that maximal signal is obtained from the area of interest.

\section{Statistical analysis:}

Statistical presentation and analysis of the present study was conducted, using the mean, standard deviation, student $t$-test, Chi-square tests by SPSS V17.

\section{Results}

First, we do analysis of the demographic data of our 40 patients which shows the mean age of the recruited patients 30 years old, the mean BMI 31 and the mean gestational age was 27 weeks of gestation as shown in Table (1).

In our study, we have 40 cases and we have found that 7 of patients were diagnosed as normal with no any congenital anomalies detected by MRI which represented $18 \%$ of all cases and 33 of those cases were diagnosed as abnormal cases who were clearly demonstrated congenital anomalies which represented $82 \%$ of all cases as suggested by MRI findings, however the results we have by 3D US were slightly different. We have 6 cases were diagnosed as normal who didn't have any congenital anomalies by this modality and represented about $15 \%$ of all cases and 34 cases were diagnosed as abnormal cases who were having congenital anomalies which represented about $85 \%$ of all cases.

According to the postnatal final diagnosis which diagnosed by imaging (2D US, X-ray) or clinical examination, we have found that 8 cases from 40 cases were diagnosed as normal and 32 cases from 40 cases were diagnosed as abnormal as shown in Table (2), Figs. (1,2,3).

In Table (3) we explained the positivity and negativity of each modality and the correlation between both with the postnatal findings which used as a standard.

We have 9 cases were diagnosed by both modalities as having hydrocephalus and more evaluation of the cases according to the cause as in Table (4). We have found 5 cases with aqueduct of sylvius stenosis with dilatation of both lateral ventricles and third ventricle. In another 3 cases, stenosis was in the foramen of monro, which was represented by dilatation of only the two lateral ventricles. Only one case was of unknown cause when examined by MRI and postnatal trans-cranial US.

We then performed test performance of 3D US which showed sensitivity of $87.5 \%$ and specificity of $25 \%$ as shown in Table (5), Fig. (4).

We then performed test performance of MRI which showed sensitivity of $93 \%$ and specificity of $62 \%$ as shown in Table (6), Fig. (5). 
The relation between demographic data including BMI (body mass index), age and gestational age and the final diagnosis were analyzed as shown in Table (7) which revealed no significant correlation and more illustration as in Figs. $(6,7,8)$.

Table (1): Descriptive analysis of demographic data including the age, BMI (body mass index) and GA (Gestational age) in the recruited patients.

\begin{tabular}{ccc}
\hline & \multicolumn{2}{c}{ Demographic data analysis } \\
\cline { 2 - 3 } & Range & Mean \pm SD \\
\hline Age & $20-40$ & $30.100 \pm 5.291$ \\
BMI & $23-39$ & $31.100 \pm 5.193$ \\
GA & $18-36$ & $27.300 \pm 6.026$ \\
\hline
\end{tabular}

Table (2): Descriptive analysis of the percentage of suggested normal and abnormal 3D Ultrasound, MRI and postnatal findings findings.

\begin{tabular}{|c|c|c|c|c|c|c|}
\hline & \multicolumn{2}{|c|}{ MRI } & \multicolumn{2}{|c|}{ US } & \multicolumn{2}{|c|}{$\begin{array}{l}\text { Postnatal } \\
\text { diagnosis }\end{array}$} \\
\hline & $\mathrm{N}$ & $\%$ & $\mathrm{~N}$ & $\%$ & $\mathrm{~N}$ & $\%$ \\
\hline Normal & 7 & 18.00 & 6 & 15.00 & 8 & 20.00 \\
\hline Abnormal & 33 & 82.00 & 34 & 85.00 & 32 & 80.00 \\
\hline Total & 40 & 100.00 & 40 & 100.00 & 40 & 100.00 \\
\hline
\end{tabular}

Table (3): Descriptive analysis of all recruited cases in the study.

\begin{tabular}{|c|c|c|c|c|}
\hline Final diagnosis & $\begin{array}{l}\text { No. of } \\
\text { cases }\end{array}$ & $\begin{array}{l}3 \mathrm{D} \\
\mathrm{US}\end{array}$ & MRI & Postnatal \\
\hline Hydrocephalus & $\begin{array}{l}8 \\
1 \\
1\end{array}$ & $\begin{array}{l}\text { +ve } \\
\text {-ve } \\
\text { +ve }\end{array}$ & $\begin{array}{l}\text { +ve } \\
\text { +ve } \\
\text {-ve }\end{array}$ & $\begin{array}{l}\text { +ve } \\
\text { +ve } \\
\text { +ve }\end{array}$ \\
\hline $\begin{array}{l}\text { Multicystic dysplastic } \\
\text { kidneys }\end{array}$ & $\begin{array}{l}3 \\
1 \\
1\end{array}$ & $\begin{array}{l}\text { +ve } \\
\text {-ve } \\
+ \text { ve }\end{array}$ & $\begin{array}{l}\text { +ve } \\
\text {-ve } \\
\text {-ve }\end{array}$ & $\begin{array}{l}\text { +ve } \\
\text {-ve } \\
\text {-ve }\end{array}$ \\
\hline $\begin{array}{l}\text { Congenital Diaphragmatic } \\
\text { Hernia }\end{array}$ & $\begin{array}{l}2 \\
1\end{array}$ & $\begin{array}{l}\text { +ve } \\
\text { +ve }\end{array}$ & $\begin{array}{l}\text { +ve } \\
+ \text { ve }\end{array}$ & $\begin{array}{l}+\mathrm{ve} \\
-\mathrm{ve}\end{array}$ \\
\hline Small bowel atresia & 1 & + ve & $+\mathrm{ve}$ & $+\mathrm{ve}$ \\
\hline Duodenal Atresia & 2 & $+\mathrm{ve}$ & + ve & $+\mathrm{ve}$ \\
\hline Pulmonary sequestration & $\begin{array}{l}1 \\
1\end{array}$ & $\begin{array}{l}+\mathrm{ve} \\
-\mathrm{ve}\end{array}$ & $\begin{array}{l}\text { +ve } \\
+\mathrm{ve}\end{array}$ & $\begin{array}{l}\text { +ve } \\
+ \text { ve }\end{array}$ \\
\hline Spina bifida & $\begin{array}{l}1 \\
1 \\
1\end{array}$ & $\begin{array}{l}\text { +ve } \\
+\mathrm{ve} \\
\text {-ve }\end{array}$ & $\begin{array}{l}\text { +ve } \\
\text { +ve } \\
\text {-ve }\end{array}$ & $\begin{array}{l}\text {-ve } \\
\text { +ve } \\
\text { +ve }\end{array}$ \\
\hline Lissencephaly & $\begin{array}{l}1 \\
1\end{array}$ & $\begin{array}{l}+\mathrm{ve} \\
-\mathrm{ve}\end{array}$ & $\begin{array}{l}-\mathrm{ve} \\
-\mathrm{ve}\end{array}$ & $\begin{array}{l}\text {-ve } \\
+ \text { ve }\end{array}$ \\
\hline Bladder exstrophy & $\begin{array}{l}1 \\
1\end{array}$ & $\begin{array}{l}\text { +ve } \\
+ \text { ve }\end{array}$ & $\begin{array}{l}\text { +ve } \\
+\mathrm{ve}\end{array}$ & $\begin{array}{l}+\mathrm{ve} \\
-\mathrm{ve}\end{array}$ \\
\hline $\begin{array}{l}\text { Porencephalic cyst } \\
\text { Meningocele } \\
\text { Anencephaly }\end{array}$ & $\begin{array}{l}1 \\
2 \\
2\end{array}$ & $\begin{array}{l}\text { +ve } \\
+ \text { ve } \\
+ \text { ve }\end{array}$ & $\begin{array}{l}\text { +ve } \\
+\mathrm{ve} \\
+\mathrm{ve}\end{array}$ & $\begin{array}{l}\text { +ve } \\
\text { +ve } \\
\text { +ve }\end{array}$ \\
\hline Corpus callosum agenesis & $\begin{array}{l}1 \\
4\end{array}$ & $\begin{array}{l}\text {-ve } \\
\text { +ve }\end{array}$ & $\begin{array}{l}\text {-ve } \\
\text { +ve }\end{array}$ & $\begin{array}{l}\text {-ve } \\
\text { +ve }\end{array}$ \\
\hline
\end{tabular}

Table (4): Descriptive analysis of the cases with hydrocephalus according to the cause.

\begin{tabular}{lcccccl}
\hline Final diagnosis & $\begin{array}{c}\text { Number } \\
\text { of cases }\end{array}$ & $\begin{array}{c}\text { 3D US } \\
\text { diagnosis }\end{array}$ & $\begin{array}{c}\text { MRI } \\
\text { diagnosis }\end{array}$ & $\begin{array}{c}\text { Postnatal } \\
\text { Findings }\end{array}$ & $\begin{array}{c}\text { Number } \\
\text { of cases }\end{array}$ & Cause \\
\hline Hydrocephalus & 8 & Positive & Positive & Positive & 5 & Aqueduct of sylvius stenosis \\
& 1 & Negative & Positive & Positive & 1 & Unknown \\
\hline
\end{tabular}

Table (5): Test performance of 3D US in prediction of fetal anomalies.

\begin{tabular}{|c|c|c|c|c|c|c|c|c|c|}
\hline \multirow{3}{*}{ US } & \multicolumn{7}{|c|}{ Final diagnosis } & \multirow{2}{*}{\multicolumn{2}{|c|}{ Chi-square }} \\
\hline & \multicolumn{2}{|c|}{ Negative } & \multicolumn{3}{|c|}{ Positive } & \multicolumn{2}{|c|}{ Total } & & \\
\hline & $\mathrm{N}$ & $\%$ & & $\mathrm{~N}$ & $\%$ & $\mathrm{~N}$ & $\%$ & $\mathrm{X}^{2}$ & $p$-value \\
\hline$-\mathrm{ve}$ & 2 & 25.00 & & 4 & 12.50 & 6 & 15.00 & 0.784 & 0.376 \\
\hline$+\mathrm{ve}$ & 6 & 75.00 & & 28 & 87.50 & 34 & 85.00 & & \\
\hline Total & 8 & 100.0 & & 32 & 100.0 & 40 & 100.00 & & \\
\hline \multicolumn{10}{|c|}{ Roc Curve } \\
\hline & Sens & & Spec. & & PPV & & NPV & Accurac & \\
\hline & 87.50 & & 25.00 & & 82.35 & & 33.33 & 75.00 & \\
\hline
\end{tabular}


Table (6): Test performance of MRI in prediction of fetal anomalies in all recruited patients.

\begin{tabular}{|c|c|c|c|c|c|c|c|c|c|}
\hline \multirow{3}{*}{ MRI } & \multicolumn{7}{|c|}{ Final diagnosis } & \multirow{2}{*}{\multicolumn{2}{|c|}{ Chi-square }} \\
\hline & \multicolumn{2}{|c|}{ Negative } & \multicolumn{3}{|c|}{ Positive } & \multicolumn{2}{|c|}{ Total } & & \\
\hline & $\mathrm{N}$ & $\%$ & & $\mathrm{~N}$ & $\%$ & $\mathrm{~N}$ & $\%$ & $\mathrm{X}^{2}$ & $p$-value \\
\hline$-\mathrm{ve}$ & 5 & 62.00 & & 2 & 7.00 & 7 & 18.00 & 10.400 & $<0.001^{*}$ \\
\hline$+\mathrm{ve}$ & 3 & 38.00 & & 30 & 93.00 & 33 & 82.00 & & \\
\hline Total & 8 & 100.00 & & 32 & 100.00 & 40 & 100.00 & & \\
\hline \multicolumn{10}{|c|}{ Roc Curve } \\
\hline & Sens. & & Spec. & & PPV & & NPV & Accuracy & \\
\hline & 93.00 & & 62.00 & & 90.00 & & 71.00 & 87.00 & \\
\hline
\end{tabular}

Table (7): Descriptive analysis in correlation between BMI (body mass index), age, GA and the final diagnosis.

\begin{tabular}{llllll}
\hline \multirow{2}{*}{ Age } & \multicolumn{2}{c}{ Final diagnosis } & & \multicolumn{2}{c}{$t$-test } \\
\cline { 2 - 3 } \cline { 5 - 6 } & Negative & Positive & & $t$ & $p$-value \\
\hline Range & $26-30$ & $19-35$ & & 0.533 & 0.597 \\
Mean \pm SD & $28.000 \pm 2.138$ & $26.875 \pm 5.824$ & & \\
$B M I:$ & & & & \\
$\quad$ Range & $36-37$ & $23-39$ & & \\
Mean \pm SD & $36.500 \pm 0.353$ & $28.500 \pm 4.544$ & & $<0.001 *$ \\
GA: & Normal & Abnormal & & \\
$\quad$ Range & $34-35$ & $18-36$ & & \\
$\quad$ Mean $\pm \mathrm{SD}$ & $34.500 \pm 0.535$ & $25.500 \pm 5.376$ & & \\
\hline
\end{tabular}

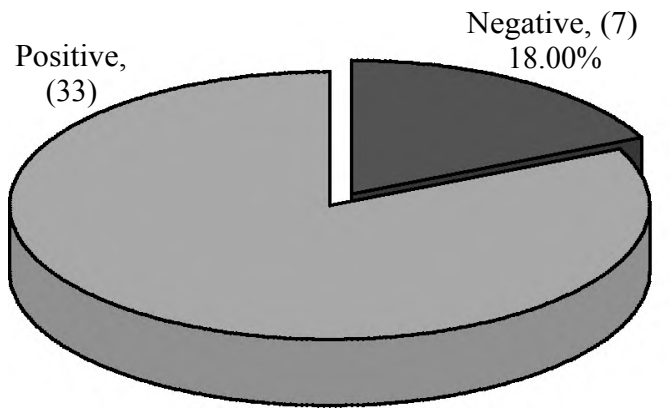

Fig. (1): Graphical presentation of the percentage of suggested normal and abnormal MRI findings.

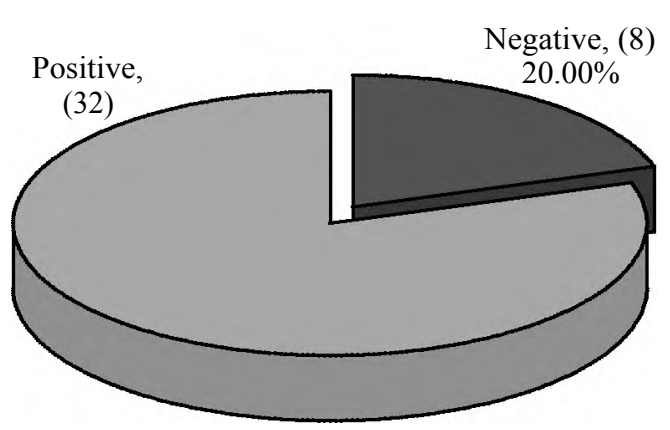

Fig. (3): Graphical presentation of the percentage of the final true diagnosis in the study.

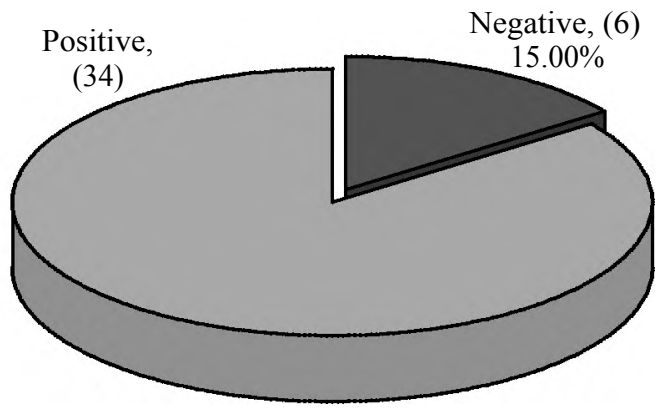

Fig. (2): 3D Graphical presentation of the percentage of suggested normal and abnormal Ultrasound findings.

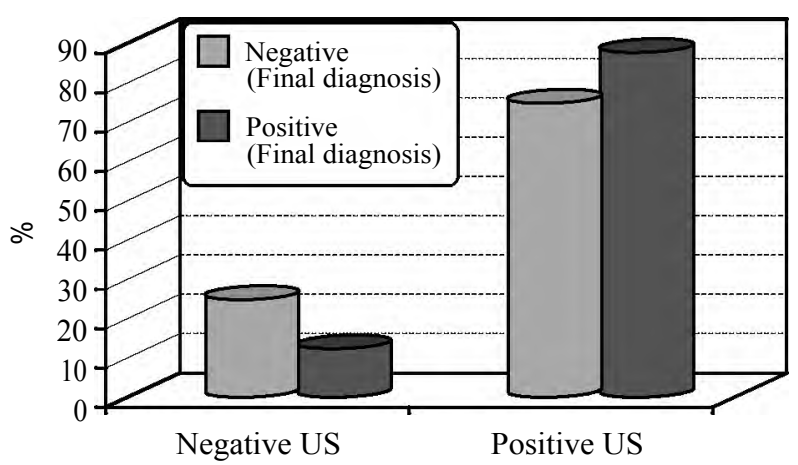

Fig. (4): Test performance of 3D US in prediction of fetal anomalies. 


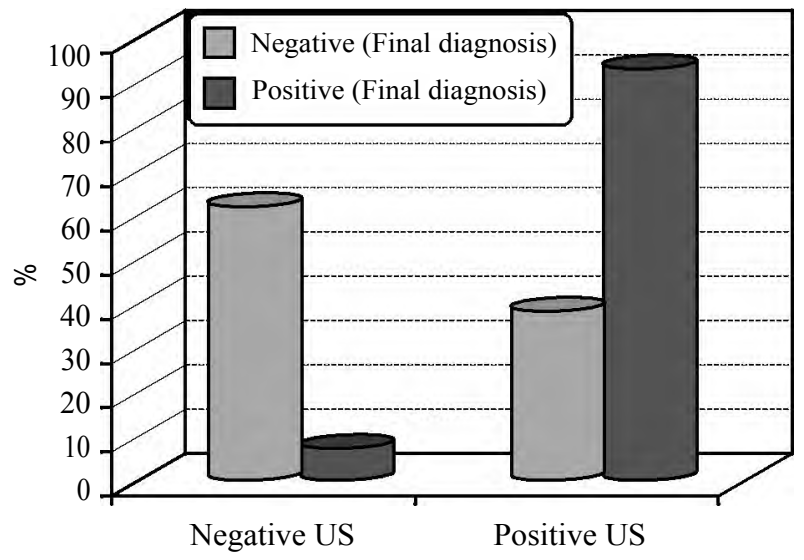

Fig. (5): Test performance of MRI in prediction of fetal anomalies in all recruited patients.

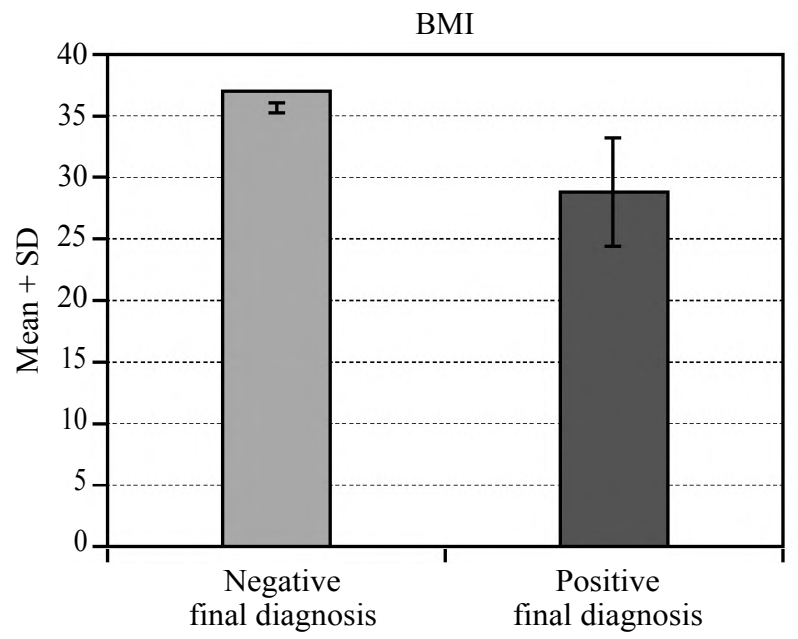

Fig. (7): Graphical presentation in correlation between BMI (body mass index) and the final diagnosis.

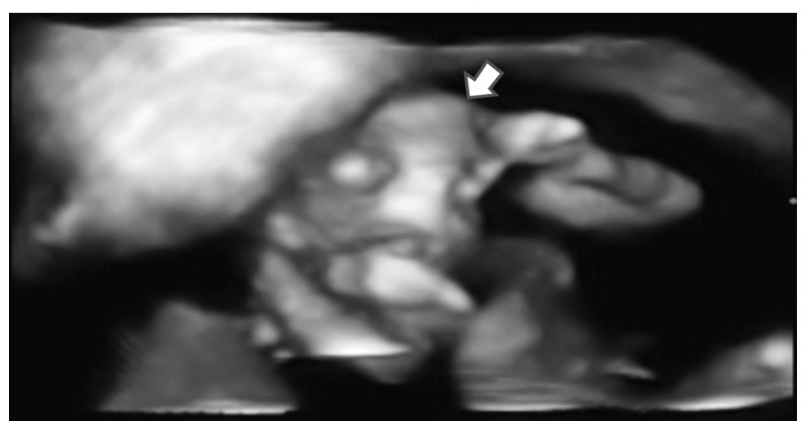

Fig. (9): 3D ultrasound image showing clearly the extent of the absence of calvarium and cerebral hemispheres (arrow) in the fetus. The frog eye sign is clearly visible in this image (the fetal orbits and eye balls protrude or bulge) of anencephaly. The prognosis is very poor and termination of pregnancy is imperative.

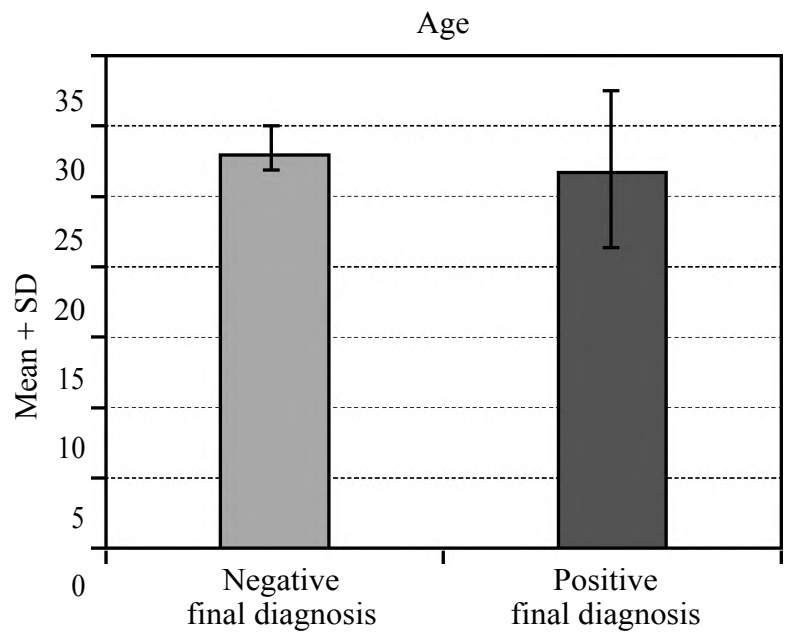

Fig. (6): Graphical presentation in correlation between the age and the final diagnosis.

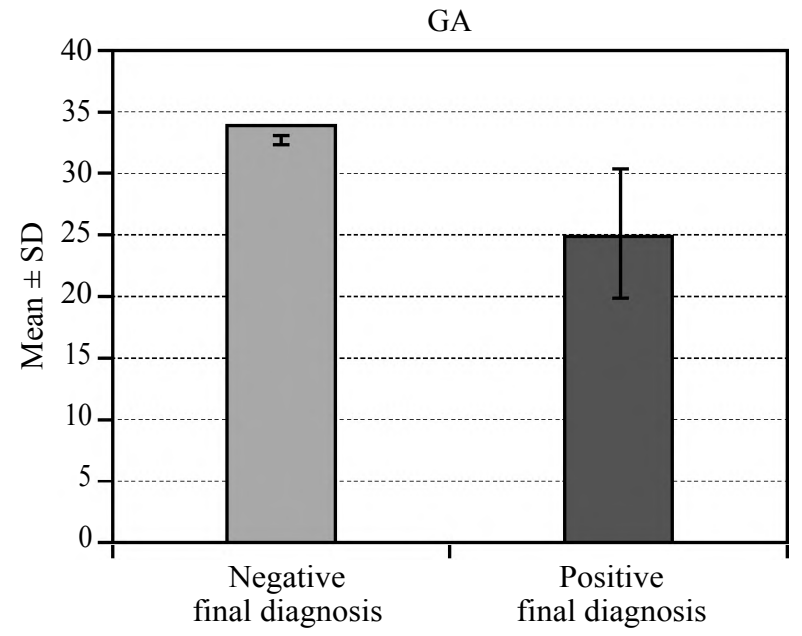

Fig. (8): Graphical presentation in correlation between gestational age (GA) and the final diagnosis.

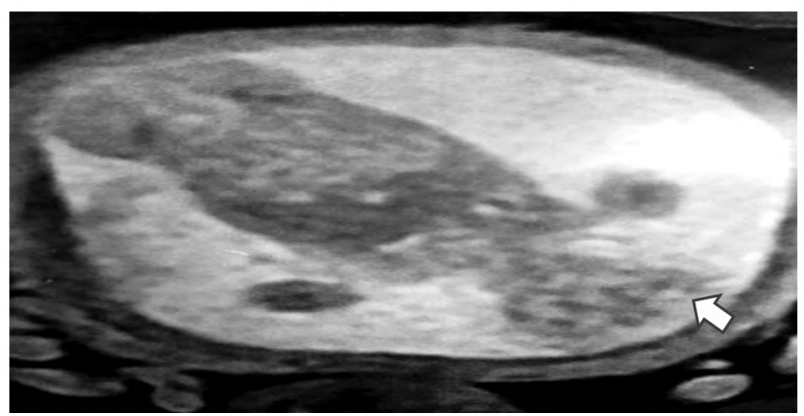

Fig. (10): A case of anencephaly with T2 weighted coronal MRI sequence showing no ossified cranium above the orbits (arrow) in a fetus aged 22 week gestational age. 


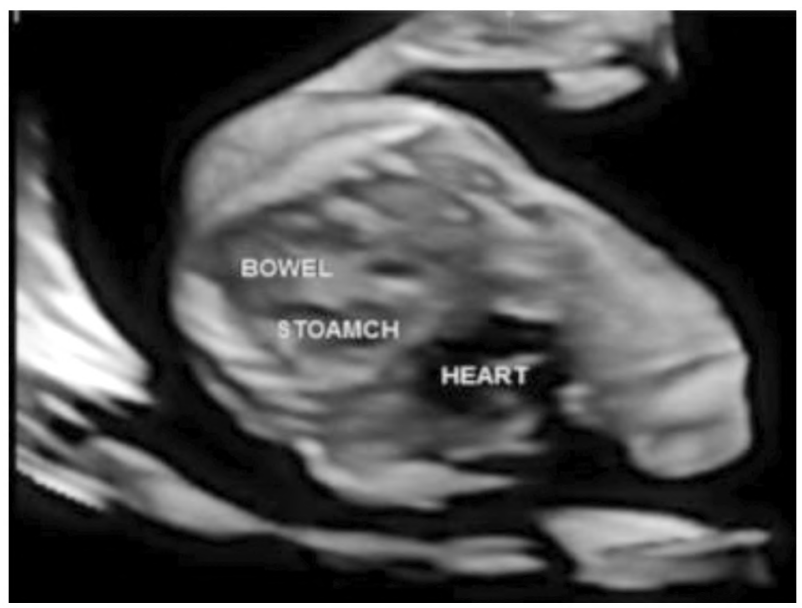

Fig. (11): Fetus of 33 week gestational age diagnosed as having congenital diaphragmatic hernia (Bochdalek type) by 3D ultrasound showing stomach bubble in the left hemithorax causing mild displacement of the heart.

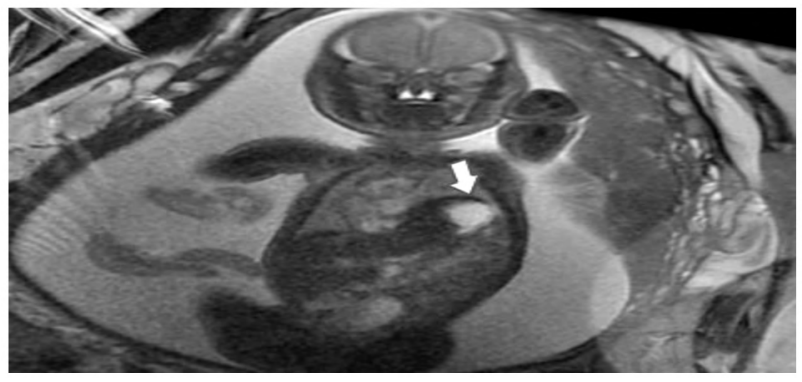

Fig. (12): MRI Coronal T2 wieghted image of left congenital diaphragmatic hernia showing bowel (arrow) in the left chest in a 33 weeks old fetus.

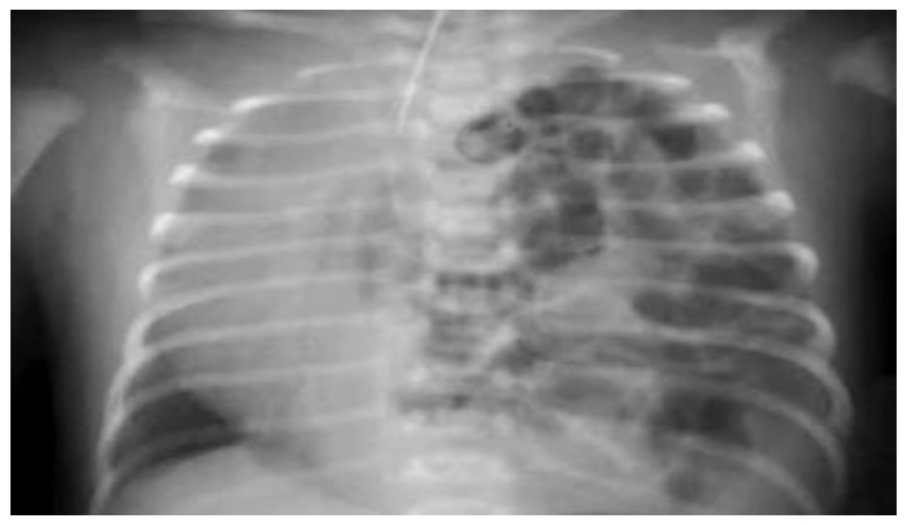

Fig. (13): Postnatal X-ray examination revealed left sided bowel in chest which confirm the diagnosis.

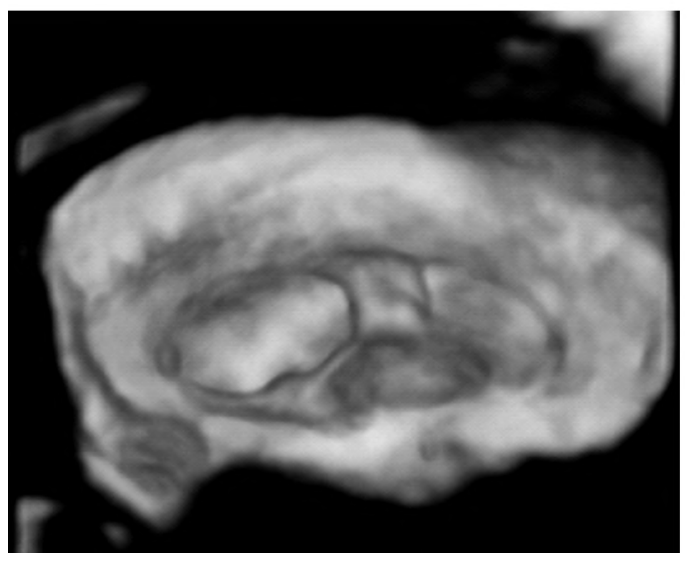

(A)

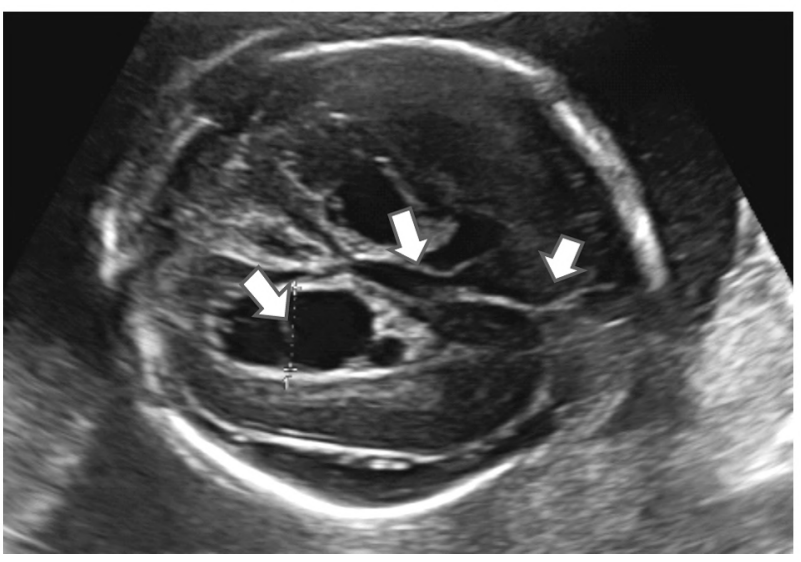

(B)

Fig. (14): 2D ultrasound image axial view (A) of 24 week with moderate dilatation of lateral ventricles and mild dilatation of the $3^{\text {rd }}$ ventricle. 3D image in sagittal view (B) showing the same finding (arrows) the cause of obstruction was not clearly seen. 

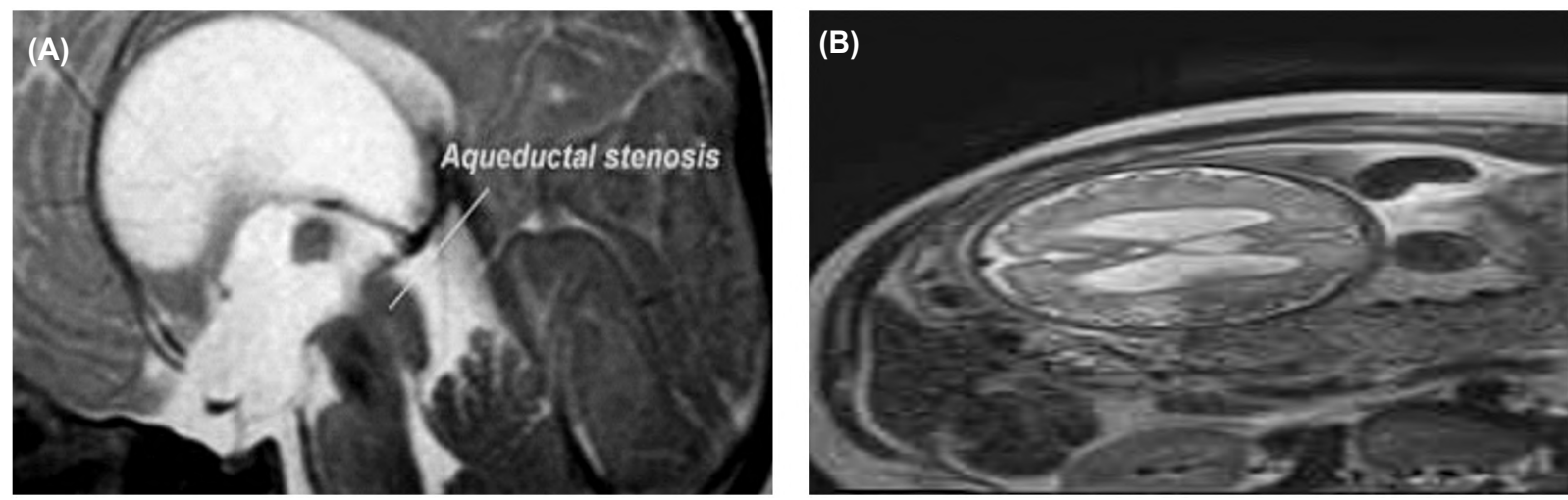

Fig. (15): MRI T2 weighted axial image (A) in a fetus of 24 week gestational age showing both lateral ventricular and mild $3^{\text {rd }}$ ventricle dilatation another sagittal view (B) showing the aqueductal stenosis (arrow) which explain the ultrasound findings.

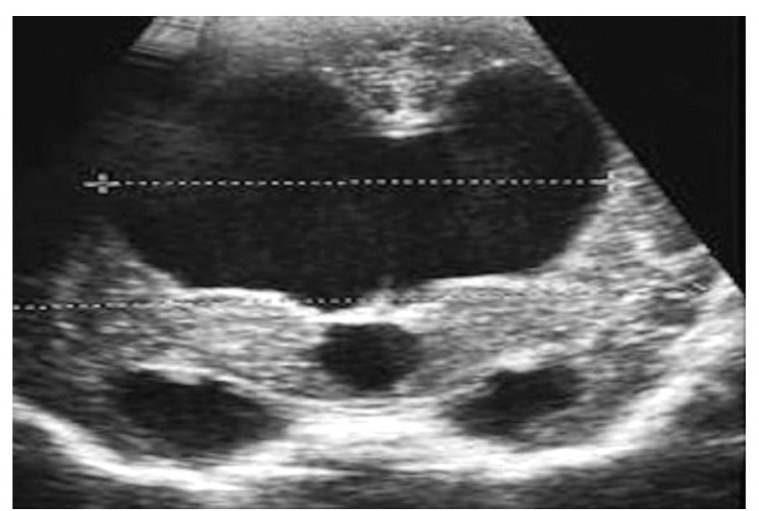

Fig. (16): Postnatal transcranial 2D US showing the same diagnosis as MRI.
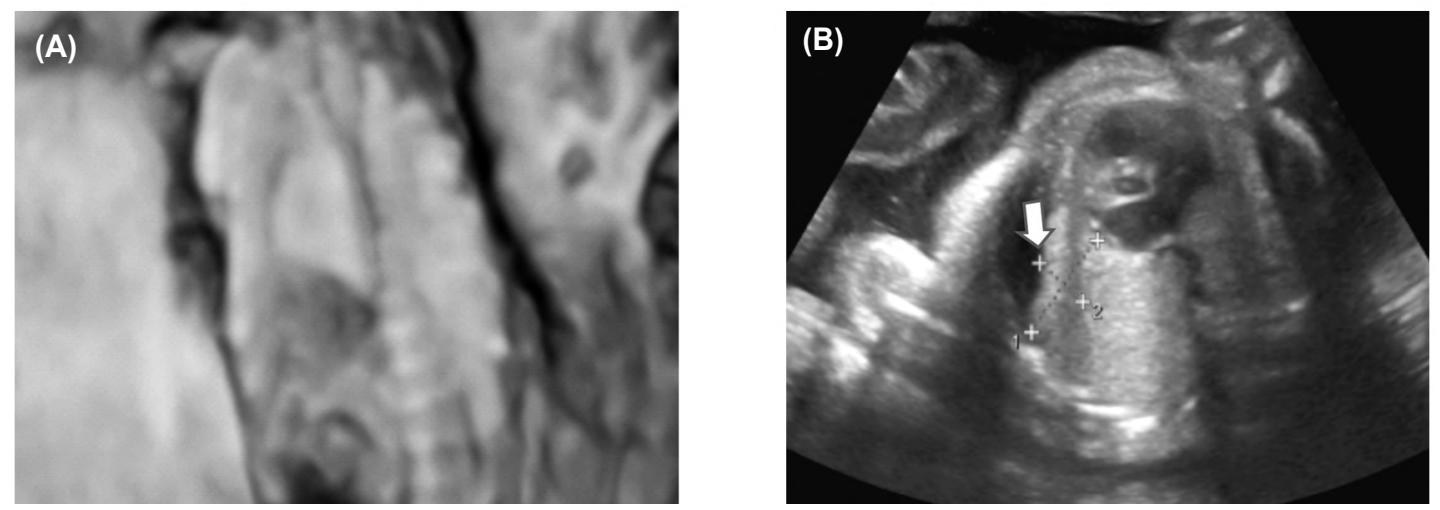

Fig. (17): A hyperechoic lesion represent pulmonary sequestration was shown by 2D US (A) in right hemithorax which was shown by 3D US (arrow) (B) In a fetus aged 26 week gestational age.
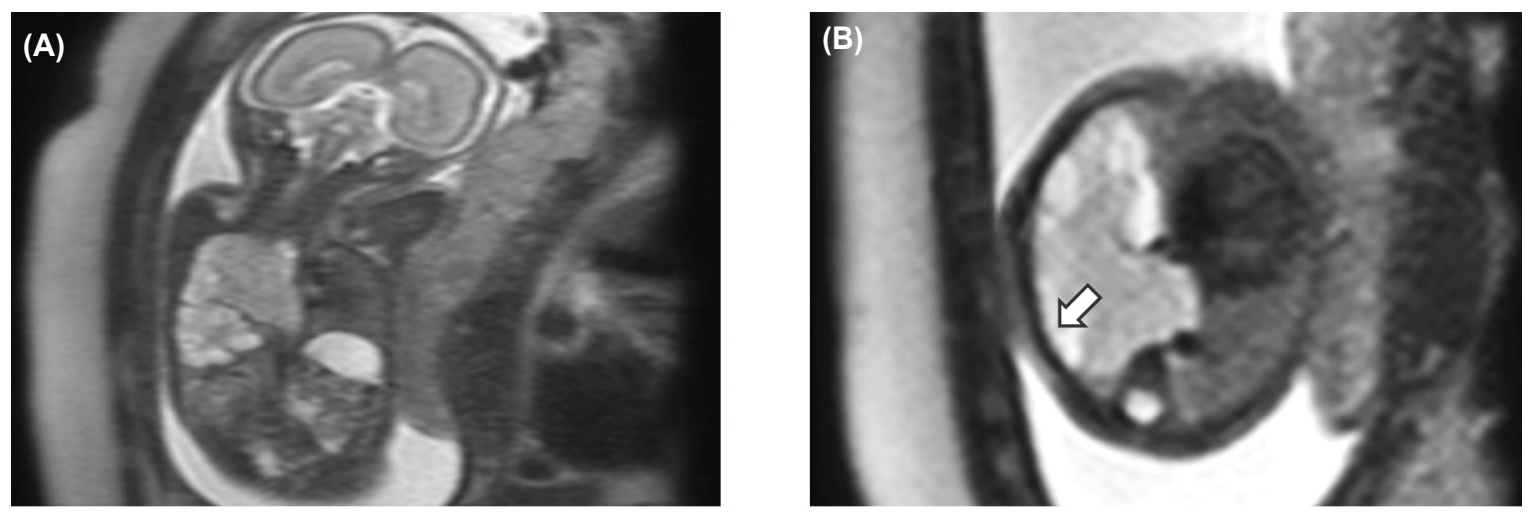

Fig. (18): Right homogenous hyperintense pulmonary sequestration in axial (A) and coronal (B) views with a feeding vessel (arrow) which is clearly demonstrated in coronal view by MRI T2 weighted sequence. 


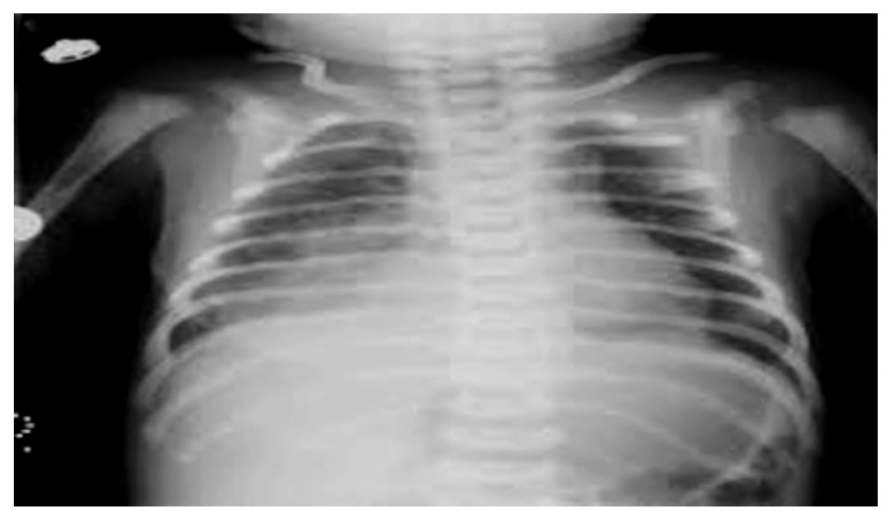

Fig. (19): Chest X-Ray examination showing right sided lower lung zone ill-defined opacity which is matching the finding by both modalities.
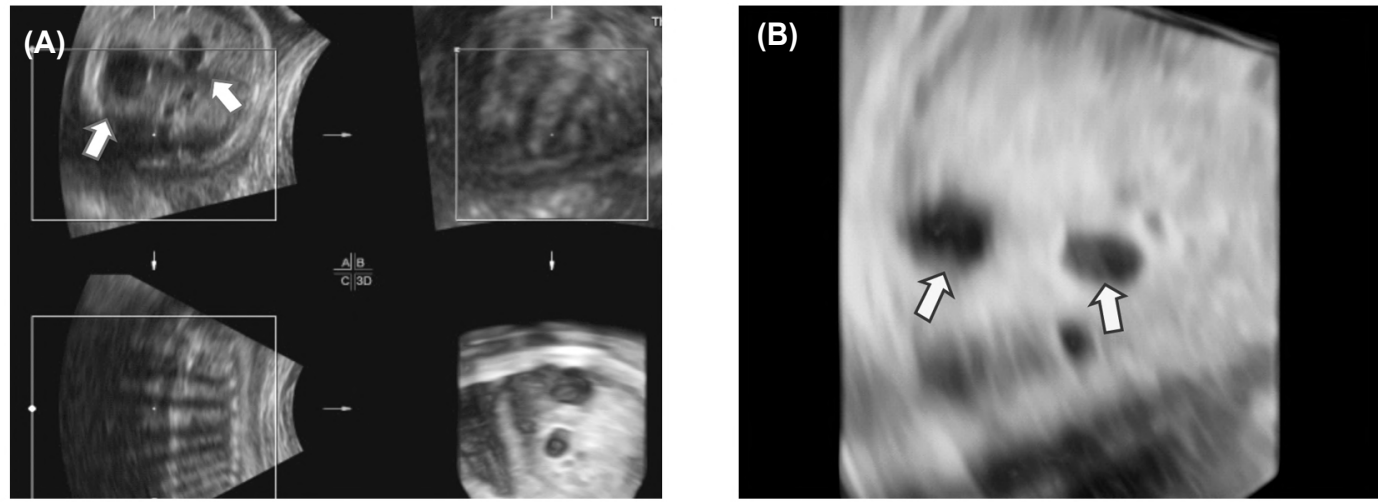

Fig. (20): A fetus of 30 weeks diagnosed as having duodenal atresia by orthogonal multiplanar views and initial surface rendered image (A) and 3D US image (B), note the presence of the two characteristic bubble sign fetal abdomen (double bubble sign) (arrows).

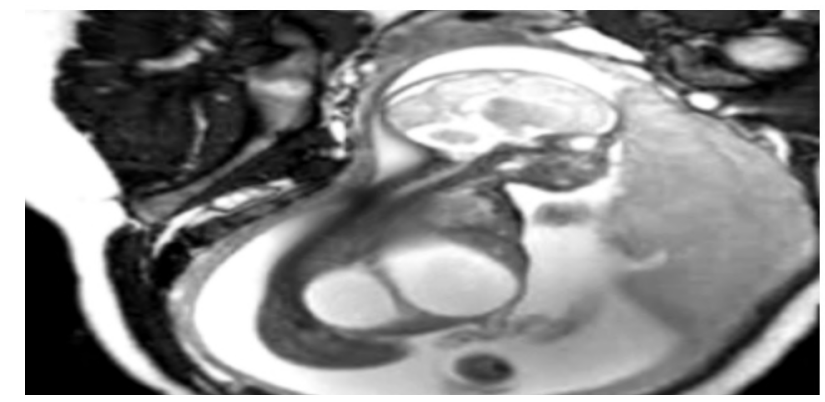

Fig. (21): MRI T2 wieghted sequence in sagittal view confirmed the diagnosis with clearly characteristic double bubble sign (arrows).

\section{Discussion}

The utility of MR imaging for fetal evaluation has evolved considerably in recent years. MR imaging is a useful adjunct to 3D US in the evaluation of complex fetal anomalies [8-12].

Griffiths et al., [13] study has found that MR imaging provided additional information in the central nervous system. In our study prenatal MR imaging when compared to 3D US in cases which concerned with all types of congenital anomalies, MR imaging showed sensitivity of (93\%) with a false positive 3 cases from 8 true normal cases

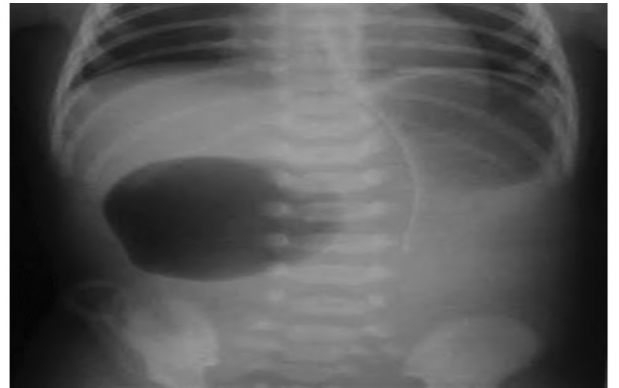

Fig. (22): PA X-ray of the neonate confirm the diagnosis, note the presence of double bubble sign (arrows).

(38\%). The first case was suspected to be congenital diaphragmatic hernia which showed a limitation in imaging by MRI because of excessive fetal movement and small amount of liquor which made a difficult visualization, also the limitation by fetal position so we didn't get a true axial view. Another suspected case of spina bifida which referred after US examination by a small spinal defect the excessive fetal movement also lead to MRI artifact and raised the suspicion of the presence of spinal defect which revealed as a normal case after postnatal examination. The $3^{\text {rd }}$ case was diagnosed by MRI as bladder extrophy which was presented by hy- 
perintense mass in the lower abdomen but revealed in postnatal examination as increased pelvic anterior compartment fat condensation with mesenchymal weakness in the lower abdomen which cause mild bulging in lower abdomen mimicking bladder extrophy.

MRI also showed a specificity of (62\%) with a false negative 2 from 32 all positive cases (7\%), the first case was: A case of spina bifida with a small spinal defect which wasn't clearly seen, the excessive fetal movement cause some limitations in imaging by MRI which then discovered postnatally. A case of in which imaging by MRI was difficult because of small liquor amount and fetal movement.

3D US showed a sensitivity of $87.5 \%$ with a false positive 6 from 8 true negative cases $(75 \%)$ and specificity of $25 \%$ with a false negative 4 from 32 true negative cases $(12.5 \%)$ and this is due to: Mother obesity, oligohydramnios, excessive fetal movement, technical factors that make visualization of some anomalies difficult and fetal position.

In the study of Goncalves et al., [14] MRI was more sensitive than 3D -US for diagnosing congenital anomalies (MRI, 88.9\% (16/18) vs. 3DUS, $66.7 \%$ (12/18) vs. 2D-US, $72.2 \%$ (13/18), it also provided additional information affecting prognosis. 2D-US, 3D-US and MRI had similar sensitivity for diagnosing non-CNS anomalies. Specificity for all anomalies was highest for 3DUS (MRI, 85.6\% (77/90) vs. 3D-US, 94.4\% (85/90) vs. 2D-US, $92.2 \%(83 / 90)$ the confidence of MRI for ruling out certain CNS abnormalities were not confirmed after delivery was lower than it was for 2D-US and 3D-US.

In our study we have found that MR imaging was accurate in $87 \%$ of our cases, however 3D US was accurate in $75 \%$ of cases so, MR imaging can sometimes provide valuable information about the fetus above and beyond that obtained at prenatal 3D US, particularly in the evaluation of anomalies of the brain.

In Rayburn William et al., [15] and Kandula et al., [10] studies they have found that prenatal 3D US has had a marked effect on patient counseling and case management with regard to CNS anomalies. However, 3D US evaluation of the fetal CNS is limited by the nonspecific appearance of some anomalies, technical factors that make visualization of the brain near the transducer difficult, and subtle parenchymal abnormalities that frequently cannot be visualized.
The corpus callosum and vermis in our research were clearly imaged by 3D US, yet these structures are often clearly visualized also with MR imaging as in D'Antonio et al., [12] study. Also we have found that MRI gave more evaluation than 3D US in a case of pulmonary sequestration, a case of lissencephaly and 2 cases of hydrocephalus, but in 6 of 40 cases, diagnosis by 3D US imaging was incorrect when they were compared with the postnatal results However, in the remaining 34 cases the 3D US results were the same as MR imaging results.

MR imaging is not limited by fetal position or maternal body habitus to the same degree as is $3 \mathrm{D}$ Ultrasonography, particularly in the third trimester as we proved in our study. MR imaging, however, is limited by fetal motion and by severe oligohydramnios as is $3 \mathrm{D}$ US [16,17]

MR imaging can be considered safe for fetal evaluation after the first trimester, but its use should be limited to cases in which complex anomalies are suspected and the 3D US results are equivocal or incomplete [18].

\section{Conclusion:}

MR imaging as an adjunct to prenatal 3D US may provide valuable information that could add to the prenatal evaluation and treatment of some fetal anomalies, particularly those involving the central nervous system.

\section{References}

1- MOHAMED N.H. and SIOUDI S.A.: Two dimensional and three dimensional ultrasonography in assessment of fetal malformation: routine versus selective use. The Egyptian Journal of Hospital Medicine Dec., 18-32, 2000.

2- POOH R.K. and KURJAK A.: Recent advances in 3D assessment of various fetal anomalies. Donald school journal of ultrasound in Obstetrics and Gynecology, 3: 1-23, 2009.

3- POOH R.K. and KURJAK A.: 3D/4D Sonography moved prenatal diagnosis of fetal anomalies from the second to the first trimester of pregnancy. The Journal of Maternalfetal and Neonatal Medicine, 25(5):433-455, 2012.

4- LOOMBA R., SHAH P.H. and ANDERSON R.H.: Fetal magnetic resonance imaging of malformation associated with heterotaxy. Cureus, 7 (5): 1-23, 2015.

5- PRAYER D., BRUGGER P.C. and PRAYER L.: Fetal MRI: Techniques and protocols.Pediatric Radiology, 34 (9): 685-693, 2004

6- YAMASHITA Y., NAMIMOTO T., TAKAHASHI M., et al.: MR imaging of the fetus by a HASTE sequence. American Journal of Roentgenology, 168 (2): 513-519, 1997.

7- BREYSEM L., BOSMANS H., DYMARKOWSKI S., et al.: The value of fast MR imaging as an adjunct to ultra- 
sound in prenatal diagnosis. European Radiology, 13 (7): 1538-1548, 2003.

8- HAMISA M., DABEES N., ATAALA W.M. and ZIADA D.: Magnetic resonance imaging versus ultrasound examination in detection of prenatal fetal brain anomalies. EJRNM, 44: 665-672, 2013

9- REDDY U.M., ABUHAMAD A.Z., LEVINE D., et al.: Fetal imaging: Executive Summary of a joint Eunice Kennedy Shriver National Institute of Child Health and Human Development, Society for Maternal fetal. Journal of Ultrasound in Medicine, 33 (5): 745-757, 2014.

10- KANDULA T., FAHEY M., CHALMERS R., et al.: Isolated ventriculomegaly on prenatal ultrasound: what does fetal MRI add? Journal of Medical Imaging and Radiation Oncology, 59 (2): 154-162, 2015.

11- KLBLE N., HUISMAN T.A.G.M., STALLMACH T., et al.: Prenatal diagnosis of a fetus with lumbar myelocystocele. Ultrasound Obstet. Gynecol., 18: 536-539, 2001.

12- D'ANTONIO F., KHALIL A., GAREL C., et al.: Systematic review and meta-analysis of isolated posterior fossa malformations on prenatal ultrasound imaging (Part 1): nomenclature, diagnostic accuracy and associated anomalies. Ultrasound in Obstetrics and Gynecology, 47 (6): 690-697, 2016.

13- GRIFFITHS P.D, BRADBURN M., CAMPBELL M.J., et al.: Use of MRI in the diagnosis of fetal brain abnor- malities in utero (MERIDIAN): A multicentre, prospective chorot study. The Lancet, 389: 538-546, 2017.

14- GONCLALVES L.F, LEE W., MODY S., et al.: Diagnostic accuracy of ultrasonography and magnetic resonance imaging for the detection of fetal anomalies: A blinded case-control study. Ultrasound Obstet. Gynecol., 48: 185192, 2016.

15- RAYBURN W.F., JOLLEY J.A. and SIMPSON L.L.: Advances in ultrasound imaging for congenital malformations during early gestation: Early ultrasound imaging for birth defect. Birth Defects Research Part A: Clinical and Molecular Teratology, 103 (4): 269-268, 2015.

16- MANGANARO L., BEMARDO S., ANTONELLI A., et al.: Fetal MRI of the central nervous system: State-ofthe-art. European Journal of Radiology, 93: 273-283, 2017.

17- KRISHNAMURTHY U., NEELAVALLI J., SWATI M., et al.: MR imaging of the fetal brain at $1.5 \mathrm{~T}$ and $0.3 \mathrm{~T}$ field strengths: comparing specific absorption rate (SAR) and image quality. Journal of Perinatal Medicine, 43 (2): 209-220, 2015.

18- VAN DOORN M., RENGERINK K.O., NEWSUM E.A., et al.: Added value of fetal MRI in fetuses with suspected brain abnormalities on neurosonography: A systematic review and meta-analysis. The Journal of Maternal-Fetal \& Neonatal Medicine, 29 (18): 2949-2961, 2016.

\section{دراسة فى دقة التشخيص بين الموجات فوق الصوتية والتصوير

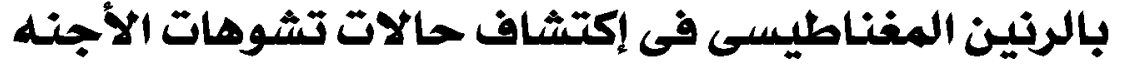

$$
\begin{aligned}
& \text { تعتبر الموجات فوق الصوتية ثلاثية الأبعاد من الطرق الأولية في تشخيص حالات تشوهات الأجنه بالإضافة إلى أنه يعتبر آمن وغير مكف فوف } \\
& \text { ويعطى تشخيص فورى. } \\
& \text { وعلى الرغم من ذلك إلى أنه يصعب التشخيص به فى حالات الحمل التى تعانى من نقص فى السائل الأمنيوبسى والسمنه والتشوهات المتعددة } \\
& \text { للأجنه ولذلك يتوجب وجود طرق بديلة التشخيص. } \\
& \text { أما بخصوص التصوير بالرنين المغناطيسى فى حالات تشوهات الأجنه فهو من الطرق الناجحة أيضاً ولكن هناك بعض الصعوبات سابقاً } \\
& \text { من حيث حركة الجنين وقجود لغط في التصوير بسبب ذلك ولكنه وبسيلة آمنة للأم والجنين ولا يوجد منها أى مخاطر على كليهما ـ وبعد ظهود } \\
& \text { بروتوكولات التصوير بالرنين المغناطيسى السريعة أصبح من السهل التصوير والتغلب على مشكلة الصركة عند الجنين. } \\
& \text { الهدف من الهوضوع: المقارنة بين التصوير بالرنين المغناطيسى والموجات فوق الصوتية ثلاثية الأبعاد في تشخيص حالات تشوهات }
\end{aligned}
$$

